\title{
Effect of Ethanol-Biodiesel-Diesel Blend on Performance and Emission Characteristics of a DI Diesel Engine
}

\author{
Sharad P. Jagtap ${ }^{1 *}$, Anand N. Pawar ${ }^{2}$, Subhash Lahane ${ }^{3}$ \\ ${ }^{1}$ Department of Mechanical Engineering, Jawaharlala Darda Institute of Engineering and Technology, Yavatmal 445001, \\ Maharashtraa, India \\ ${ }^{2}$ Maharashtra State Board of Technical Education, Regional Office, Aurangabad 431005, Maharashtra, India \\ ${ }^{3}$ Department of Mechanical Engineering, College of Engineering, Pune 411005, Maharashtra, India
}

Corresponding Author Email: jagtapsp@gmail.com

https://doi.org/10.18280/ijht.390119

Received: 2 September 2019

Accepted: 20 December 2020

\section{Keywords:}

biodiesel, diesel engine, ethanol-biodieseldiesel (EBD) blend

\begin{abstract}
A significant increase in every nation's energy demand and insufficient conventional energy reservoirs for long duration, there became necessary requirement to shift from nonrenewable to renewable energy sources. Diesel and biodiesel fuels have different thermo physical properties; hence performance and emission output parameters are also different compares with each other. For effective utilization of biodiesel, the characteristics of conventional single cylinder diesel engine with changing load and static speed (1500 rev/min) conditions are evaluated. The baseline diesel, biodiesel - diesel (BD) B08 [8\% biodiesel blended with diesel] and ethanol-biodiesel-diesel (EBD) E05B08 [5\% ethanol and $8 \%$ biodiesel blended with diesel] by v/v ratio are used for experimentation. Brake thermal efficiency (BTE) reduced from $29.14 \%$ with diesel to $27.64 \%$ with biodiesel and $28.49 \%$ with ethanol blends. It is observed that BTE reduced by $1.5 \%$ with biodiesel blend and $0.65 \%$ only with ethanol blend. The CO, HC and opacity of exhaust gas pollutants are reduced with biodiesel blend fuel and also further reduced with EBD blend. NOx formation with B08 fuel is enhanced to 1967 ppm from 1557 ppm of baseline diesel whereas it is slightly increased to 1734 ppm by E05B08 fuel.
\end{abstract}

\section{INTRODUCTION}

For development of any country, energy is high intensive input. Now a day's energy demand increases and to satisfy the demand, requires huge investments to meet them. Energy billing expenses are also highly intensive and hence critically efficient utilization is required. Maintaining efficient energy use has been cultured since from first oil shock (year 1973 oil crisis). In today's scenario energy efficiency became highly essential because of being the most cost-effective and competitive internationally. Energy efficiency also leads to mitigate global climatic change [1]. Recent higher industrial and automobile sector growth leads more fossil fuel consumption rate and hence government of every nation promoting research and development to use environmentally sound new and renewable energy sources. Many researchers have carried out research work on biodiesel application for many years for compression ignition (CI) engines. Biodiesel has most promising renewable and clean alternative fuel stage and can be blended with diesel fuel for little or no modification. It is biodegradable, no-toxic and sulfur, aromatics in biodiesel is also lower [2]. The presence of sulfur and aromatics in diesel fuel result in formation of particulate matter [3]. In transesterification process, kinematic viscosity reduces and calorific value increases. Many experimental investigations to evaluates characteristics on conventional engine with various biodiesels namely from, cashew nuts [4], corn oil [5], cottonseed oil [6], peanut oil [7], beef tallow [8], karanja oil [3] and so on have been carried out by researchers. Pollutants from fuel combustion emission causes known or doubted destructive effects on human health and environment. Air pollutants can be sprayed long distances. They chemically react in the atmosphere and forms secondary pollutants like acid rain or ozone. Pollutants like oxides of nitrogen (NOx), Hydrocarbons (HC), carbon monoxide (CO), and particulates are generated by diesel engines. These pollutants deteriorate urban air quality. Diesel and biodiesel fuel have different thermo physical properties hence the combustion characteristics are also different for variable load condition. Biodiesel having low carbon content $(10 \%)$ and more oxygen (11\%) than conventional diesel fuel [9]. Hence, variations in exhaust emission and engine performance have been noticed by researchers. Thermo physical variations in conventional diesel and biodiesel changes net heat release rate characteristics. It reduces $\mathrm{CO}, \mathrm{HC}$, and smoke levels pointedly but upturns the NOx contribution [10-12]. Arunkumar et al. [13] have reported that brake specific fuel consumption (BSFC) is increased by $4 \%$ and break thermal efficiency (BTE) reduced by $2.2 \%$ with B20 composite of castor biodiesel (20\% biodiesel $+80 \%$ diesel) compares to diesel application. This is because of low calorific value of biodiesel in B20 blend fuels. $\mathrm{CO}$ and $\mathrm{HC}$ are reduced by 8.6 and $8.1 \%$ respectively. Biodiesel has higher bulk modulus than diesel. For B20 fuel blend, the injection timing advances and hence ignition delay is reduced [3]. Further biodiesel fuel having inbuilt dissolved oxygen, leads to early combustion starts and consequently reduced ignition delay found. This shows higher peak pressure during combustion and consequently peak in-cylinder 
temperature increase. Thus may cause more NOx formation in biodiesel application. Hence ethanol can be an option to abbreviate NOx formation and improve performance if blended with biodiesel blend. As biodiesel molecules have polar end in nature which has affinity to ethanol hence it is active additive for avoiding the separation of diesel from ethanol [14]. Ethanol has lower cetane number and higher latent heat for fuel vaporization than diesel and biodiesel fuels. It affects longer ignition delay which leads to retardation in start of combustion. Also it takes heat from combustion chamber for vaporization and reduces in-cylinder temperature. How et al. [15] noticed the effect of ethanol addition in coconut biodiesel-diesel blend. They have studied B20 (20\% biodiesel and 80\% diesel) and E05B20 (5\% ethanol+20\% biodiesel and $75 \%$ diesel). It is observed that the E05B20 blend showed lower NOx, smoke, and $\mathrm{CO}$ emission and improved BTE than baseline diesel and B20 fuel. In this experimental investigation, Jatropha biodiesel obtained from transesterification of plant Jatropha carcass oil. Jatropha carcass plants can grow in dry and waste lands and involves very minor attention. The jatropha plants cannot graze by cattle. Extracted oil is non-edible. About $25 \%$ oil yield is possible by crushing plant seeds. Double crushing of seeds can increase the yield to $28.5 \%$ while solvent extraction may up to $30 \%$ [16]. The transesterification process is used to esterify crude oil and convert it into biodiesel which has reduced viscosity and increased cetane number [17]. A sample of $8 \%$ (by volume) biodiesel is blended with diesel and tested at rated load. The performance and emission output parameters are compared with baseline diesel. Finally 5\% ethanol and $8 \%$ biodiesel is blended with baseline diesel to form ethanolbiodiesel-diesel blend (E05B08) and compared its characteristics with biodiesel-diesel blend and baseline diesel.

\section{MATERIAL AND METHODOLOGY}

The experimentation for biodiesel application to evaluate the performance and emission characteristics consists of single cylinder, four strokes kirlosker make, TV1 model with water cooled and eddy current dynamometer attached engine. The specifications are given in Table 1 .

The engine test rig layout is presented in Figure 1. Test rig is fitted with various measuring devices like fuel flow, temperature, load, combustion pressure and crank angle measurement with data acquisition system. Two sets of rotameters connected to water pump line which maintains water flow for engine and calorimeter. Fuel flow rate is measured by using burette and air flow rate is measured by airbox method respectively through various transmitters. Thermocouples (K-type) are attached to measure temperatures at various necessary places. A piezo sensor attached in the cylinder head for combustion gas pressure measure. For crank angle position detection, a rotary encoder is fitted on the engine shaft. Both pressure and crank angle signals are simultaneously measured and communicated to computer through data acquisition processor.

For measurements of all emission characteristics, externally attachable facility of exhaust gas analyzers and smoke meter are installed. For evaluation of exhaust gas characteristics, exhaust gas and smoke meters specifications are mentioned in Table 2.

Many researchers [18-20] have discussed the transesterification process to derive biodiesel from crude vegetable oil. As direct use of Jatropha crude oil may have high viscosity, poor volatility, and lower heating value characteristics can cause some problems such as injector chocking, sticky piston rings, thickening lubrication oil with long term operation and filter sticking. Discussed difficulties can be diminished by doing transesterification process of crude jatropha oil to form monoesters (or biodiesel). At $\mathrm{m} / \mathrm{s}$ Parshuram Bio Urja, Pune has supplied the esterified jatropha biodiesel. In present experimental investigation, $8 \%$ esterified jatropha oil (EJO) blend with baseline diesel (B08) and 5\% ethanol (99.8\% pure), 8\% EJO blend with baseline diesel (E05B08) is used to observe the performance and emission at variable load (25, 50, 75 and 100\%) and constant speed (1500 rpm) condition. Characteristics are compared with baseline diesel fuel operation. Thermo-physical properties of diesel, esterified jatropha oil (EJO) and ethanol are mentioned in Table 3

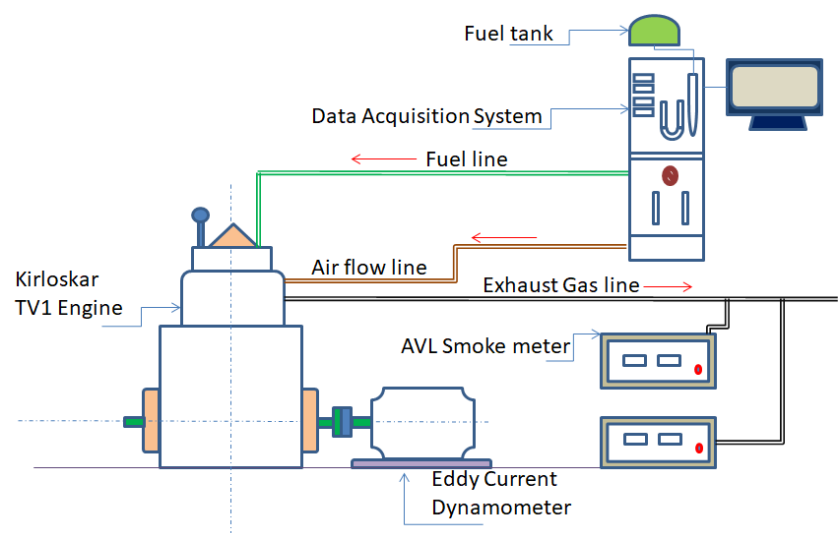

Figure 1. The engine test rig layout

Table 1. Specifications of diesel engine

\begin{tabular}{cc}
\hline Rated output & 5 HP $(3.67 \mathbf{~ k W})$ \\
\hline Speed & $1500 \mathrm{RPM}$ \\
\hline CR & $18: 01$ \\
\hline Pressure for fuel injector & 210 bar \\
\hline Dynamometer & $\begin{array}{c}\text { Eddy current, water cooled with } \\
\text { loading unit }\end{array}$ \\
\hline
\end{tabular}

Table 2. Equipments specification for measuring emission

\begin{tabular}{|c|c|c|c|c|}
\hline Instrument & $\begin{array}{l}\text { Make } \\
\text { (model) }\end{array}$ & $\begin{array}{l}\text { Measuring } \\
\text { parameter }\end{array}$ & Range & Accuracy \\
\hline \multirow{4}{*}{$\begin{array}{l}\text { Exhaust gas } \\
\text { analyser }\end{array}$} & \multirow{4}{*}{ AVL (444N) } & $\mathrm{CO}$ & $0-10 \%$ of vol & $<0.6 \%$ vol: $\pm 0.03 \%$ vol $>0.6 \%$ vol: $\pm 5 \%$ vol \\
\hline & & $\mathrm{CO}_{2}$ & $0-20 \%$ of vol & $<10 \%$ vol: $\pm 0.5 \%$ vol $>10 \%$ vol: $\pm 5 \%$ vol \\
\hline & & $\mathrm{HC}$ & 0-20000 ppm & $\begin{array}{c}<200 \mathrm{ppm}: \pm 10 \mathrm{ppm}>200 \mathrm{ppm}: \pm 5 \% \text { of } \\
\text { ind.value }\end{array}$ \\
\hline & & NOx & $0-5000 \mathrm{ppm}$ & $<500 \mathrm{ppm}: \pm 50 \mathrm{ppm}$ \\
\hline Smoke meter & AVL (437) & Smoke opacity & $\begin{array}{c}0-100 \% \text { capacity } \\
\text { in } \%\end{array}$ & $\pm 1 \%$ full scale reading \\
\hline
\end{tabular}


Table 3. Thermo-physical properties of base fuels

\begin{tabular}{cccc}
\hline Property & Diesel & Ethanol & EJO \\
\hline Density $\left(\mathrm{kg} / \mathrm{m}^{3}\right)$ & 846 & 789 & 870 \\
\hline Kinematic Viscosity $(\mathrm{cSt})$ & 2.51 & 1.09 & 12.408 \\
\hline Calorific Value $(\mathrm{kJ} / \mathrm{kg})$ & 42600 & 35500 & 26700 \\
\hline Flash Point $\left({ }^{\circ} \mathrm{C}\right)$ & 64 & 13 & 180 \\
\hline Cetane Number & 46 & 7 & 51.3 \\
\hline
\end{tabular}

\section{RESULT AND DISCUSSION}

\subsection{Brake Specific Fuel Consumption (BSFC) and Brake Thermal Efficiency (BTE)}

Compression ignition engines have inherent fuel-flexibility for various biodiesel application. Due to lower heat value of biodiesel than conventional diesel fuel, the experimentation was carried out with blending of $8 \%$ esterified jatropha oil in conventional diesel by $\mathrm{v} / \mathrm{v}$ ratio (called B08 blend). The comparative performance of a single-cylinder diesel engine with conventional diesel fuel and B08 blend was evaluated. The Brake Specific energy consumption (BSEC) with the variable load at constant speed for the B08 biodiesel blend is compared with baseline diesel as shown in the Figure 2. The BSFC is a useful parameter for analyzing the optimal working condition of an engine. Biodiesel has lower calorific value, slightly more density and, deprived injector spray features. For all variable loads, the BSFC of B08 fuel has slightly higher value than baseline diesel. Hence, for improvement in spray characteristics of biodiesel blend, an attempt is made to add ethanol in existing blend. By adding ethanol in existing biodiesel blend, decrease the blend viscosity, increase its volatility and improve its cold-flow properties of ethanolbiodiesel-diesel blend fuel. Moreover, the higher oxygen content in ethanol leads to improve fuel combustion. Hence the BSFC at E05B08 is reduced. From experimentation result it is noticed that the BSFC slightly reduces during ethanolbiodiesel-diesel blends (E05B08) that of same biodiesel-diesel blend (B08) application. The SFC of B08 and E05B08 blends are 0.31 and $0.30 \mathrm{Kg} / \mathrm{kWh}$ respectively compare to baseline diesel of $0.29 \mathrm{Kg} / \mathrm{kWh}$ at maximum load condition.

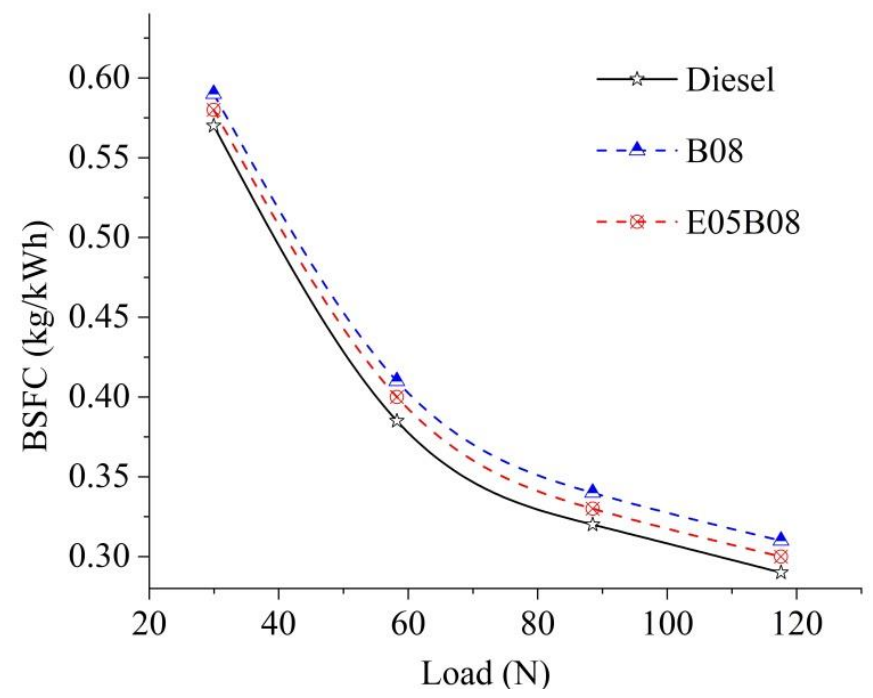

Figure 2. The comparative variations in $\mathrm{BSFC}(\mathrm{Kg} / \mathrm{kWh})$ with variable load (N) for B08, E05B08 with baseline diesel
The break thermal efficiency (BTE) is the ratio of energy in the brake power to the fuel energy. It was calculated according to following equations:

$$
\begin{gathered}
\text { BTE }=\frac{\text { Brake Power }}{\text { Fuel energy }} \\
=\frac{\text { Break Power }(\mathrm{kW}) \times 3600}{\text { Fuel flow }(\mathrm{kg} / \mathrm{Hr}) \times \text { Calorific value }(\mathrm{kJ} / \mathrm{kg})} \times 100
\end{gathered}
$$

Break thermal efficiency was increased with E05B08 fuel operation as shown in Figure 3. It was due to reduction in fuel consumption and lower calorific value. The BTE of B08 fuel was lower than conventional diesel fuel due to its higher BSFC and lower calorific value as shown in Figure 2.

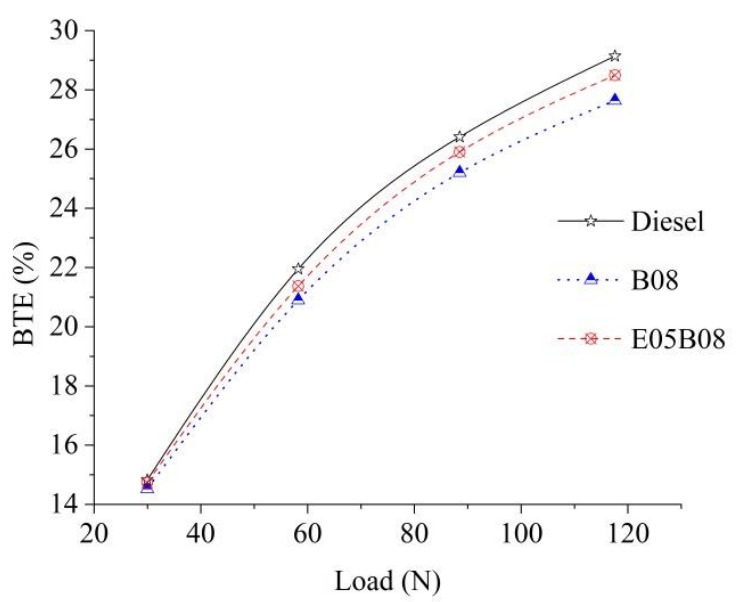

Figure 3. The comparative variations in BTE (\%) with variable load $(\mathrm{N})$ for B08, E05B08 with baseline diesel

Similarly the BTE is reduced to $27.64 \%$ to $28.49 \%$ with B08 and E05B08 blend fuels respectively compares to baseline diesel of $29.14 \%$ at rated load condition.

\subsection{Carbon Monoxide (CO) and Hydrocarbon (HC)}

Figure 4 and Figure 5 indicates the comparative deviations in $\mathrm{CO}$ and $\mathrm{HC}$ with variable load and at constant speed of 1500 $\mathrm{rpm}$. The $\mathrm{CO}$ and $\mathrm{HC}$ are decreased with jatropha biodiesel B08 application at variable load.

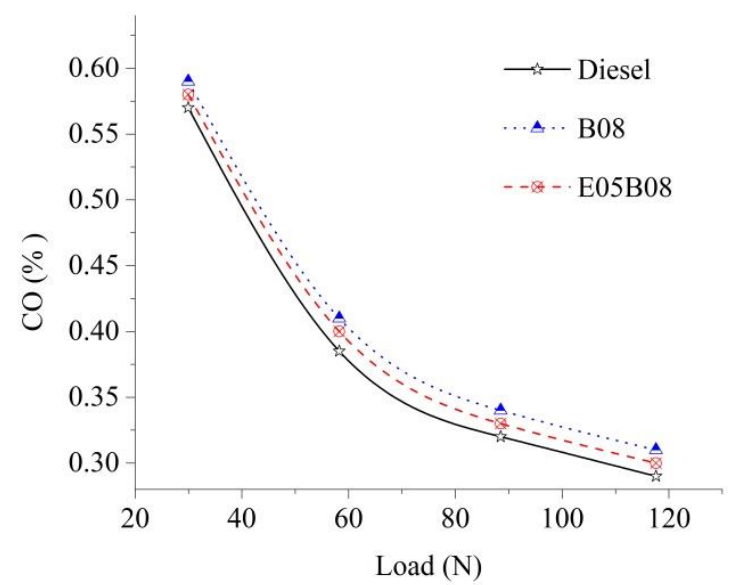

Figure 4. The comparative variations in $\mathrm{CO}(\%$ by exhaust gas volume) with variable load (N) for B08, E05B08 with baseline diesel 


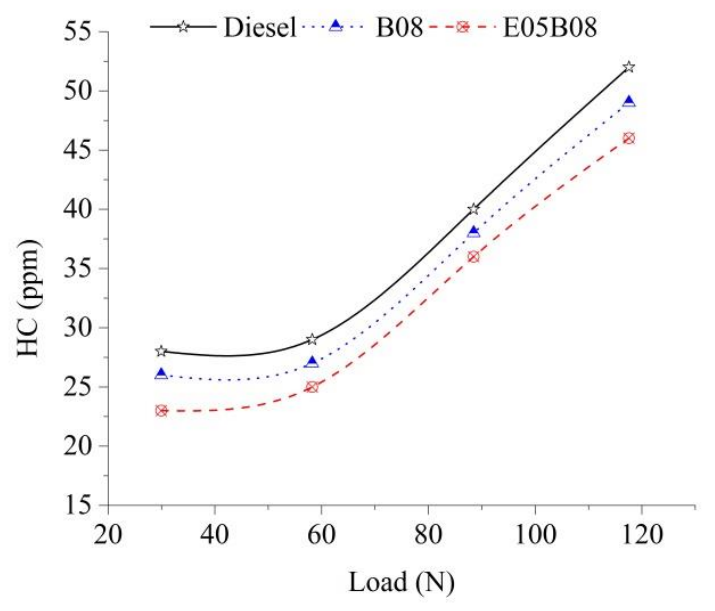

Figure 5. The comparative variations in $\mathrm{HC}$ (ppm) with variable load $(\mathrm{N})$ for B08, E05B08 with baseline pure diesel

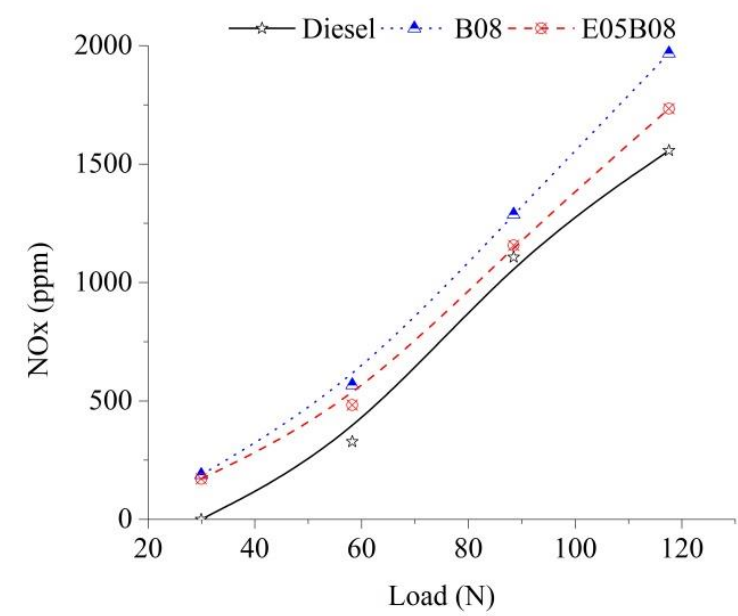

Figure 6. The comparative variations in $\mathrm{NOx}(\mathrm{ppm})$ with variable load (N) for B04, E05B08 with baseline diesel

Due to reduction in ignition delay period with biodiesel blend [21], it increases the engine ability for better and cleaner combustion hence; $\mathrm{CO}$ and $\mathrm{HC}$ emission are reduced. The variation for biodiesel blends B08 is compared with baseline diesel at rated load. $\mathrm{CO}$ emission is decreased from $0.086 \%$ with baseline diesel to $0.077 \%$.

Further E05B08 fuel operation; it again reduced to $0.072 \%$ as shown in Figure 4. Unburned hydrocarbon (HC) is an important emission characteristic for determining the emission behavior of the engine. It was reduced in B08 and E05B08 fuel operations. This is because of better combustion of biodiesel blends inside the combustion chamber due to availability of oxygen atom in biodiesel. The $\mathrm{HC}$ emission decreased from $52 \mathrm{ppm}$ with pure diesel to $49 \mathrm{ppm}$ at B08 fuel application. Further it reduced to $46 \mathrm{ppm}$ at E05B08 fuel application as shown in Figure 5. But during biodiesel blend it is found that the NOx emission is increased from $1557 \mathrm{ppm}$ to $1967 \mathrm{ppm}$.

\subsection{Oxides of nitrogen (NOx)}

NOx are mainly formed in I.C. engine due to oxidation of nitrogen which is present with aspiring air for combustion. The oxidation of nitrogen receipts at higher temperature. Due to higher temperature levels in biodiesel blends, the NOx formation possibility is also higher compares with baseline diesel shown in Figure 6. For biodiesel blend (B08) operation, burnt more amount of fuel and consequently more air entered at higher temperature. Hence, for biodiesel blend (B08) operation, burned more amount of fuel and consequently more air entered at higher temperature, in certain way the NOx emission can be reduced by introducing ethanol in existing biodiesel (E05B08) as shown in Figure 5. Due to adding 5\% ethanol in existing biodiesel blend (to form E05B08), the peak pressure during combustion cycle reduces compared with B08 which leads combustion happens at lower temperature.

\subsection{Opacity (\%)}

The smoke is significantly reduced for both biodiesel (B08) and ethanol (E05B08) blend fuel compare with the pure diesel fuel at all load shown in Figure 7. As blend fuels contains more oxygen at the core of the spray during combustion, which frontrunners to better combustion ability and consecutively reduction in smoke opacity. Ethanol's blend increases the volatility of mixture also further improves combustion phenomenon and mitigates smoke opacity. Smoke opacity is decreased from $24.6 \%$ with baseline diesel to $23.5 \%$ and $22.11 \%$ for B08 and E05B08 blends respectively at rated load condition.

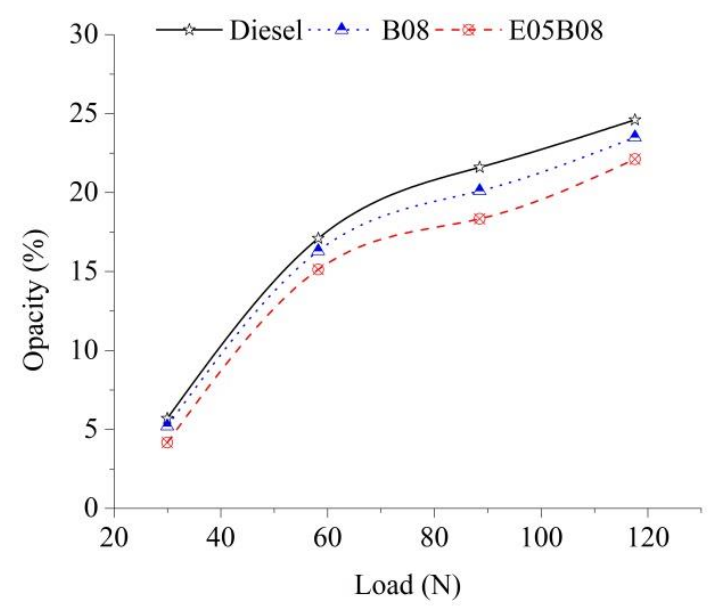

Figure 7. The comparative variations in Opacity (\%) with variable load $(\mathrm{N})$ for B08, E05B08 with baseline diesel

For evaluation of effective utilization biodiesel, the above experimentally investigated performance and emission characteristics of B08 and E05B08 fuels are compared by percentage change with baseline diesel as shown in Figure 8. The comparing characteristics are carried out at rated load with $1500 \mathrm{rpm}$.

The BSFC is increased by $6.45 \%$ and $3.33 \%$ with B08 and E05B08 fuels respectively. The BSFC found improved in ethanol blending with same biodiesel share because of improved combustion. Pertaining to variations of specific fuel consumptions, the BTE of B08 and E05B08 fuels is reduced by $1.5 \%$ and $0.65 \%$ respectively. This reduction is due to lower heating values of blend fuels. The BTE reduction in ethanol blending is improved compares with B08 fuel. The exhaust emission is continuously improved in both blends except NOx emission. The $\mathrm{CO}$ and $\mathrm{HC}$ pollutants in exhaust gas are decreased by $11.69 \%$ and $6.12 \%$ for B08 fuel respectively. Similarly these pollutants are also decreased by $19.44 \%$ and $13.04 \%$ for E05B08 fuel respectively. Also the opacity of exhaust smoke is decreased by $4.68 \%$ and $11.26 \%$ for B08 and E05B08 fuels respectively. 


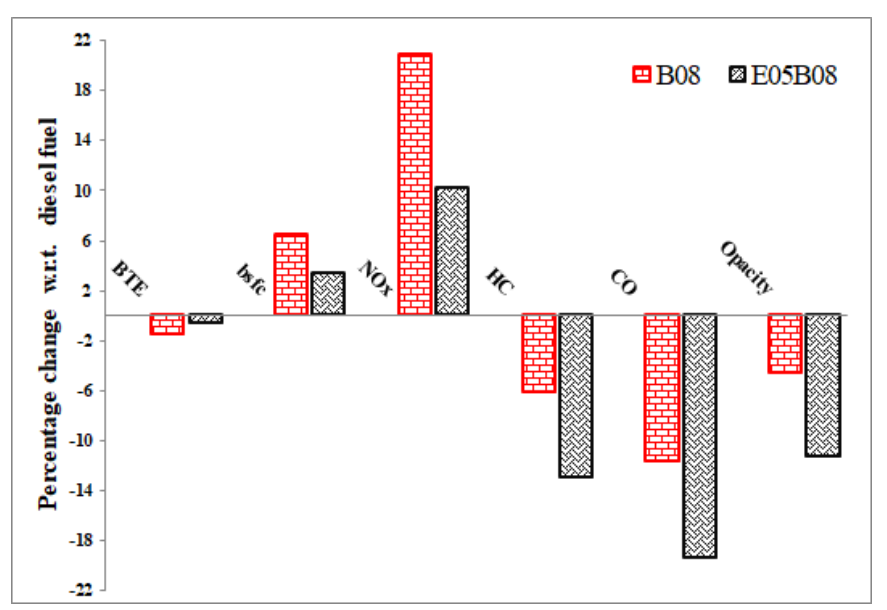

Figure 8. The comparative percentage change in performance and emission of B08, E05B08 with baseline diesel

The NOx emission is increased by $20.84 \%$ with biodiesel blend B08. This is due to higher peak pressure and higher peak temperature during combustion of injected fuel. This experimental investigation shows that by adding $5 \%$ ethanol in same biodiesel utilization, effect of increased in NOx emission is inhibited to almost half upto $10.21 \%$.

\section{CONCLUSIONS}

The subsequent conclusions are proposed based on the result analysis of the single cylinder, four strokes, diesel engine with baseline diesel, EJO blend-B08 and ethanolbiodiesel-diesel (EBD) blend - E05B08.

- The BTE at higher load is decreases with biodiesel blend (B08) which could be slightly improved with EBD blend (E05B08).

- NOx formation for biodiesel blend (B8) operation is enhanced that of baseline diesel whereas it is marginally reduces by adding ethanol in the biodiesel blend (E5B8).

- The CO and HC pollutants in exhaust gas is reduced with biodiesel blend fuel and also further reduced with EBD blend.

- The opacity of exhaust gas is reduced with biodiesel blend fuel and also further reduced with EBD blend.

Ethanol-biodiesel-diesel (EBD) blends can be a better alternative for effective utilization of biodiesel fuel; on the other hand, there is a need of advance research on the effects of EBD blend on oxidation, toxicity and safety affinity and remedies on engine operation.

\section{REFERENCES}

[1] PIB (Press Information Bureau) (2014). Environment Protection under Constitutional, Framework of India, 4 June 2014. http://pib.nic.in/newsite/PrintRelease.aspx?relid=10541 1.

[2] Shelke, P.S., Sakhare, N.M., Lahane, S. (2016). Investigation of combustion characteristics of a cottonseed biodiesel fuelled diesel engine. Procedia Technology, 25: 1049-1055. https://doi.org/10.1016/j.protcy.2016.08.205

[3] Lahane, S., Subramanian, K.A. (2015). Effect of different percentages of biodiesel-diesel blends on injection, spray, combustion, performance, and emission characteristics of a diesel engine. Fuel, 139: 537-545. https://doi.org/10.1016/j.fuel.2014.09.036

[4] Velmurugan, A., Loganathan, M. (2013). Performance and emission characteristics of a DI diesel engine fuelled with cashew nut shell liquid (CNSL)-diesel blends. International Journal of Mechanical and Mechatronics Engineering, 5(10): 2057-2062. https://doi.org/10.5281/zenodo.1060062

[5] Senthil Kumar, R., Loganathan, M., Tamilarasan, P. (2014). Performance and emission characteristic of DI diesel engine with preheating corn oil methyl ester. International Journal of Mechanical Engineering and Technology (IJMET), 5(1): 79-89.

[6] Aydin, H., Bayindir, H. (2010). Performance and emission analysis of cottonseed oil methyl ester in a diesel engine. Renew Energy, 35(3): 588-592. https://doi.org/10.1016/j.renene.2009.08.009

[7] Santos, B.S., Capareda, S.C., Capunitan, J.A. (2013). Engine performance and exhaust emissions of peanut oil biodiesel. Journal of Sustainable Bioenergy Systems, 3(4): 272-286. https://doi.org/10.4236/jsbs.2013.34037

[8] Selvam, D.J.P.,, Vadivel, K. (2012). Performance and emission analysis of DI diesel engine fuelled with methyl esters of beef tallow and diesel blends. Procedia Engineering, 38: 342-358. https://doi.org/10.1016/j.proeng.2012.06.043

[9] Dwivedi, G., Jain, S., Sharma, M.P. (2013). Diesel engine performance and emission analysis using biodiesel from various oil sources - Review. Journal of Materials and Environmental Science, 4(4): 434-447.

[10] Dash, SK., Dash, S., Lingfa, P. (2017). Comparative assessment of performance and emission analysis of a diesel engine fueled with bio-diesel prepared from different sources. Jr. of Industrial Pollution Control, 33(2): 1114-1119.

[11] Rakopoulos, D.C. (2012). Heat release analysis of combustion in heavy-duty turbocharged diesel engine operating on blends of diesel fuel with cottonseed or sunflower oils and their bio-diesel. Fuel, 96: 524-534. https://doi.org/10.1016/j.fuel.2011.12.063

[12] Dhinesh, B., Lalvani, J.I.J.R., Parthasarathy, M., Annamalai, K. (2016). An assessment on performance, emission and combustion characteristics of single cylinder diesel engine powered by Cymbopogon flexuosus biofuel. Energy Conversion and Management, 117: 466-474. https://doi.org/10.1016/j.enconman.2016.03.049

[13] Arunkumar, M., Kannan, M., Murali, G. (2019). Experimental studies on engine performance and emission characteristics using castor biodiesel as fuel in CI engine. Renewable Energy, 131: 737-744. https://doi.org/10.1016/j.renene.2018.07.096

[14] Armas, O., Gómez, A., Mata, C., Ramos, A. (2013). Particle size distributions from a city bus fuelled with ethanol-biodiesel-diesel fuel blends. Fuel, 111: 393-400. https://doi.org/10.1016/j.fuel.2013.03.036

[15] How, H.G., Masjuki, H.H., Kalam, M.A., Teoh, Y.H. (2014). Engine performance, emission and combustion characteristics of a common-rail diesel engine fuelled with bioethanol as a fuel additive in coconut oil biodiesel 
blends. Energy Procedia, 61: 1655-1659. https://doi.org/10.1016/j.egypro.2014.12.185

[16] Krishna, M.V.S.M., Rao, V.V.R.S., Reddy, T.K.K., Murthy, P.V.K. (2014). Comparative studies on performance evaluation of di diesel engine with high grade low heat rejection combustion chamber with carbureted alcohols and crude jatropha oil. Renewable and Sustainable Energy Reviews, 36: 1-19. https://doi.org/10.1016/j.rser.2014.04.020

[17] Rao, B.S., Murthy, V.K., Ramjee, E., Krishna, M.V.S.M. (2015). Studies on exhaust emissions and combustion characteristics of tobacco seed oil in crude form and biodiesel from a high grade low heat rejection diesel engine. Journal of Industrial Engineering and Research, 5(2): 1-11.

[18] Rajendra Prasath, B., Tamilporai, P., Shabir, M.F. (2010). Analysis of combustion, performance and emission characteristics of low heat rejection engine using biodiesel. International Journal of Thermal Sciences, $\quad 49(12)$ : 2483-2490. https://doi.org/10.1016/j.ijthermalsci.2010.07.010

[19] Parida, M.K., Rout, A.K. (2017). Investigation of performance and emission analysis of Argemone mexicana biodiesel blends as a fuel in a DICI engine at part load conditions. Energy Sources, Part A: Recovery, Utilization, and Environmental Effects, 39(6): 623-629. https://doi.org/10.1080/15567036.2016.1252812

[20] Hazar, H., Ozturk, U. (2010). The effects of $\mathrm{Al}_{2} \mathrm{O}_{3}-\mathrm{TiO}_{2}$ coating in a diesel engine on performance and emission of corn oil methyl ester. Renewable Energy, 35(10): 2211-6. https://doi.org/10.1016/j.renene.2010.02.028

[21] Jagtap, S.P., Pawar, A.N., Lahane, S. (2020). Improving the usability of biodiesel blend in low heat rejection diesel engine through combustion, performance and emission analysis. Renewable Energy, 155: 628-644. https://doi.org/10.1016/j.renene.2020.03.115 